\title{
Lake Kinneret (Israel): New insights into Holocene regional palaeoclimate variability based on high resolution multi-proxy analysis
}

\section{Hannah Vossel ${ }^{1}$, Patricia Roeser ${ }^{2}$, Thomas Litt ${ }^{1} \&$ Jane M. Reed $^{3}$}

${ }^{1}$ Rheinische Friedrich-Wilhelms-University of Bonn, Steinmann Institute of Geology, Mineralogy \& Paleontology, Nussallee 8, 53115 Bonn, Germany; Corresponding author email: hvossel@uni-bonn.de

${ }^{2}$ CEREGE UM34, Aix-Marseille Université, CNRS, IRD, Collège de France, Technopôle de l’Arbois, BP 80, F-13545, Aix en Provence, France

${ }^{3}$ Geography, School of Environmental Sciences, University of Hull, Cottingham Road, Hull, HU6 7RX, United Kingdom

This is the accepted version of the article published as Vossel, H, Roeser, P., Litt, T., and Reed, J. (2018). Lake Kinneret (Israel): New insights into Holocene regional palaeoclimate variability based on high resolution multi-proxy analysis. Holocene, 28(9), 1395-1410. doi:10.1177/0959683618777071 


\section{Abstract:}

The southern Levant is a Mediterranean climate zone of complex variability in which uncertainty remains in regional palaeoclimate reconstruction. In spite of the proven value of diatoms in circum-Mediterranean palaeoenvironmental research, their potential remains largely unexplored in the southern Levant region. In this study, we generate a new, highresolution multi-proxy record for the last ca 9,000 cal yrs BP, supported by diatom data and key biological, mineralogical and geochemical indicators preserved in a $17.8 \mathrm{~m}$ long sediment sequence recovered from Lake Kinneret (the Sea of Galilee), Israel.

During the Holocene, well-correlated shifts in the diatom, minero-geochemical and palynological data indicate marked lake-level variation over time as well as changes in the trophic state of Lake Kinneret. Our results are particularly important in improving the reconstruction of Holocene lake-level variation, and thus past moisture availability. Diatominferred lake-level oscillations correlate well with the output from climatic models from the Levantine region and clarify previous uncertainty concerning regional variation in moisture availability. The Early Holocene (from ca. 9,000 cal yrs BP to 7,400 cal yrs BP) was characterized by lake-level shifts due to fluctuating dry-wet climate conditions. During the mid-Holocene (from 7,400 to 2,200 cal yrs BP), a stable, deep lake-level phase persisted due to high humidity. The lake level of modern Lake Kinneret fluctuates seasonally with available moisture, but has also been influenced for ca. 2,000 years by the impacts of water abstraction for human consumption and agriculture.

Over the last 9,000 cal yrs BP, the trophic state of Lake Kinneret has changed from an oligotrophic to a meso- to eutrophic environment, mainly triggered by increased human impact from around 2,200 cal yrs BP onwards. The lake's ecosystem status was not strongly affected by the documented major changes in human occupation patterns during the midHolocene, when a relatively stable environment persisted. 
Keywords: diatoms, palaeoecology, Sea of Galilee, Levant, human activity, lacustrine carbonates 


\section{Introduction:}

The Eastern Mediterranean is a key region for palaeoclimate research due to its considerable sensitivity to climate change because of its location between the North Atlantic pressure systems, the monsoons of East Africa and India and the continental climate of Europe (Lionello et al., 2006). This complexity translates itself into considerable complexity in palaeoenvironmental archive data, with climate change manifesting itself in the combined influence of precipitation and temperature change on lake levels and limnological processes, which may be mediated to a greater or lesser extent by other factors including catchment processes and human activities, to name but a few. In spite of expansion of Holocene circumMediterranean research in recent decades (Robinson et al., 2006, Finné et al., 2011), our understanding of past environmental variability and its possible drivers is still limited.

The Levantine region, located in the transition zone between the Saharo-Arabian desert belt and the subtropical Mediterranean, on the western end of the Fertile Crescent, has a long history of human occupation and therefore represents an ideal area for investigating the complex relationships between climatic, environmental and societal changes (Issar and Zohar, 2004, Frumkin et al., 2011, Richter et al., 2012). The Early Holocene is reported as the wettest phase in the past 25, 000 years across the Levant and eastern Mediterranean (Robinson et al., 2006), whereas a trend towards more aridity with punctual short-term climate shifts, having a notable impact on human occupation patterns, is assumed for the mid- to Late Holocene (Rambeau and Black, 2011). A series of reviews have recently been compiled which consider the palaeoenvironmental evidence derived from proxies such as pollen analyses, stable isotopes (e.g. from speleothems, lake sediments or snails), from geomorphological indicators (such as palaeo-shorelines), and from the archaeological record for the Southern Levant during the Holocene (e.g. Issar, 2003, Robinson et al., 2006, Finné et al., 2011, Rambeau and Black, 2011, Bar-Matthews et al., 2017, Litt and Ohlwein, 2017, Rosen and Rosen, 2017, 
Torfstein and Enzel, 2017). Establishing a coherent linkage between different sources of data in the southern Levant (e.g. lacustrine and marine sediment records, speleothem data) can be challenging, e.g. due to distinctive gradients in topography and moisture availability. It is not understood whether apparent discrepancies are a result of real spatial variability in climate response (Rambeau, 2010), that of differences in response thresholds between palaeoenvironmental archives, or are a function of data quality. The uncertainty is probably due in part to the rarity in the southern Levant of well-dated, continuous multi-proxy records spanning the entire Holocene. With several lakes in the region, palaeolimnology offers the potential to reduce uncertainty surrounding continental variability.

Lake-level reconstructions from the past Lake Lisan, the Dead Sea (Torfstein et al., 2013, Kushnir and Stein, 2010) and the northern freshwater body of Lake Kinneret (Hazan et al., 2004, Hazan et al., 2005) have been achieved, but uncertainties remain. Current understanding of Dead Sea lake-level variability during the Holocene is reviewed by Kushnir and Stein (2010). A lake-level reconstruction from Lake Kinneret based on sedimentological identification of radiocarbon-dated palaeo-shorelines (Hazan et al., 2004, Hazan et al., 2005) offers a fragmentary Holocene reconstruction. Lake Kinneret is thought to have stood at $\sim 212$ $\mathrm{m}$ below sea level (mbsl) during most of the Holocene, i.e. similar to the modern lake, yet there were periods when the lake level declined and the shallower southern sediments were exposed (Hazan et al., 2005, Stein, 2014). There is no existing evidence for full desiccation of the lake during the past 10,000 years (Langgut et al., 2015). Several authors emphasize the still incomplete picture of Holocene lake-level evolution, and thus the uncertain character of local changes in moisture availability (Hazan et al., 2004, Hazan et al., 2005, Stein, 2014, Schiebel and Litt, 2017).

To date, palaeolimnological reconstructions based on diatoms (single-celled siliceous algae; Bacillariophyceae) have been limited in the southern Levant, in spite of their high sensitivity to a wide range of limnological variables (van Dam et al., 1994) and proven potential in 
palaeoclimate research in Mediterranean climate zones (Battarbee et al., 2001, Cvetkoska et al., 2014, Zhang et al., 2014). Previous diatom-based palaeolimnological studies at Lake Kinneret comprise a low-resolution analysis of the changing character of planktonic diatoms in the southern part of the lake over the last 5,000 years (Pollingher et al., 1984), and a palaeoecological assessment of recent environmental change in the diatom flora of five short cores (Ehrlich, 1985). A detailed mineral and geochemical investigation based on sediments from Lake Kinneret covering the entire Holocene was also lacking.

In this study, we present the results of high-resolution diatom analysis combined with minerogeochemical analysis of a $17.8 \mathrm{~m}$ long Holocene sediment sequence from Lake Kinneret. Our results are compared to previously-published palynological data from the same core (Langgut et al., 2013, 2015, 2016, Schiebel, 2013, Schiebel and Litt, 2017), the longest and most continuous Holocene sequence yet retrieved from the lake. This study aims to exploit the value of diatoms as palaeolimnological proxy indicator for lake-level variation, and thus local changes in moisture availability. We assess critically evidence for confounding factors of additional ecological change such as shifts in lake productivity (Wilson et al., 2008) or human impact since Neolithic times (e.g. Rollefson and Köhler-Rollefson, 1992, Maher et al., 2011), which may affect interpretation. Our results are set in the context of known regional records, considering short-term climate events, to test whether there is coherency in regional patterns of climate change during the Holocene.

\section{Site description and limnology of Lake Kinneret}

Lake Kinneret (from the Hebrew word kinnōr = 'harp', reflecting the shape of the lake) is also known as the Sea of Galilee or Lake Tiberias and, with a surface elevation of $210 \mathrm{mbsl}$, is the lowest-lying freshwater lake on Earth. The lake is located in the north of Israel in the northern 
part of the Jordan Rift Valley $\left(32^{\circ} 48^{\prime} 08.12^{\prime \prime} \mathrm{N}, 35^{\circ} 35^{\prime} 20.62^{\prime \prime} \mathrm{E}\right.$; figure 1), which is filled with alluvial and lacustrine sediments of Neogene and Pleistocene age. The lake is situated, together with the Dead Sea Basin, on the tectonically-active Dead Sea Transform Fault (DSTF), which currently forms a more than $1000 \mathrm{~km}$ long fault system connecting the divergent plate boundary along the Red Sea with the Eastern Anatolian Fault (EAF) in Turkey (Hurwitz et al., 2002). The modern and Holocene Sea of Galilee has evolved from ancient water bodies that filled the Kinneret tectonic depression during the Late Pleistocene, such as the former Lake Lisan (Hazan et al., 2005). The lake catchment is mainly composed of Cretaceous to Eocene carbonate rocks with extensive karst. Neogene and Pleistocene basalt is also common, especially in the Golan Heights on the eastern shore, forming escarpments of up to $500 \mathrm{~m}$ in height around the lake (Sneh et al., 1998).

The Kinneret region is currently characterized by a typical semi-arid Mediterranean climate (Baruch, 1986), with an average annual precipitation of $400 \mathrm{~mm}$ and a mean annual temperature of $21^{\circ} \mathrm{C}$ (figure 1). Northern Israel receives most of its precipitation from midlatitude Cyprus lows, which generate westerlies and transport moist air from the Mediterranean Sea into the region (Ziv et al., 2014). The mean annual precipitation and temperature vary considerably from northern to southern Israel, partly as a function of topography. Maximum precipitation occurs further north, on Mt. Hermon (Golan Heights), with an average of $1600 \mathrm{~mm} /$ year. In the Jordan Valley precipitation varies from $700 \mathrm{~mm} /$ year in the Hula basin to $300 \mathrm{~mm}$ in the Beth-Shean region (Langgut et al., 2016). There is a sharp transition to a fully arid climate in the south. Annual temperatures increase approximately linearly with decreasing precipitation.

The lake is the largest natural freshwater body in Israel $\left(22 \times 12 \mathrm{~km} ; 167 \mathrm{~km}^{2}\right)$ and by water abstraction is a major source of drinking and irrigation water. A bathymetric map is provided in figure 1. The catchment area $\left(2730 \mathrm{~km}^{2}\right)$ extends to parts of the Upper Galilee in NE Israel, the Golan Heights, the Hermon range (with the peak of Mt. Hermon at $2814 \mathrm{~m}$ above sea 
level (masl)) and the southern Anti-Lebanon mountains (Baruch, 1986). The Jordan River flows into and out of the lake and is its main freshwater input $\left(434 \times 10^{6} \mathrm{~m}^{3} /\right.$ year $)$, draining southwards to the Dead Sea. The lake is also fed by several saline springs, which influence its salinity and geochemical composition (Stiller et al., 2009, Stein, 2014, Kolodny et al., 1999, Nishri et al., 1999), such that the water is slightly oligosaline (table 1, total dissolved solids ca. $600 \mathrm{mg} \mathrm{L}^{-1}$, Nishri et al., 1999, Katz and Nishri, 2013). Analysis of the modern diatom flora (Vossel unpublished) shows the presence of halophilous diatom taxa close to the saline springs, along the western shore, confirming that these, rather than evaporative concentration, are the main cause of the subtle increase in salinity.

[insert table 1]

Total annual water inflow is about $629 \times 10^{6} \mathrm{~m}^{3}$ comprising the inflow of the Jordan River, direct catchment runoff, saline springs, direct precipitation and other water sources (Rimmer and Givati, 2014a). Modern lake level can fluctuate by up to $4 \mathrm{~m}$ a year depending on precipitation, evaporation $\left(230 \times 10^{6} \mathrm{~m}^{3} /\right.$ year $)$ and water use for human consumption and agriculture (National Water Carrier, 2012).

Lake Kinneret is warm monomictic, being stratified with an anoxic hypolimnion from May to December and fully mixed from December to April (Gophen, 2003, Katz and Nishri, 2013). The mixing cycle of the water column is closely linked to the bio-geochemical signature imprinted in the sediments, and directly affects the fluxes of calcite precipitated from the water column towards the bottom of the lake (Katz and Nishri, 2013). Biologically-induced calcite precipitation occurs in spring and early summer (Katz and Nishri, 2013).

The modern phytoplankton flora of Lake Kinneret is dominated by dinoflagellates, with a low proportion of diatoms, cyanobacteria and chlorophytes. As diatoms are a minor component of the phytoplankton biomass (Pollingher et al., 1984), they have not previously been a focus for ecological research, although, with more than 200 reported species (Round, 1978), they are an important component of the benthic flora. The most common planktonic taxa are Cyclotella 
spp., Stephanodiscus spp., Aulacoseira granulata, which are often accompanied by the periphytic Brachysira spp. The most common benthic taxa are Amphora pediculus, Achnanthes sensu lato spp., Navicula spp., Synedra ulna and Rhoicosphenia curvata. A detailed species list is provided in Zohary et al. (2014).

[insert figure 1]

\section{Material and Methods}

\section{Sediment cores, sedimentology and chronology}

In March 2010, two parallel sediment cores (core KI_10_I and KI_10_II) were recovered from a water depth of $38.8 \mathrm{~m}$ at the central, deepest part of the lake basin $\left(32^{\circ} 49^{\prime} 13.8^{\prime}{ }^{\prime} \mathrm{N}\right.$, $35^{\circ} 35^{\prime} 19.7^{\prime}$ 'E; figure 1). Cores were retrieved from a UWITEC Universal Sampling Platform (http://www.uwitec.at), using a piston corer for successive two-meter sections. Sediment cores were offset by $0.5 \mathrm{~m}$ to allow construction of a continuous composite profile (Schiebel, 2013). Sediment cores are stored in a cooling chamber at $4^{\circ} \mathrm{C}$ at the University of Bonn. The recovered sediment cores consist of homogenous greyish to brown silt and clay deposits (figure 5); only the upper $25 \mathrm{~cm}$ of sediments show lamination, possibly due to the construction of the Degania Dam in 1932 (A. Nishri, personal communication). Only one notable sediment disturbance is apparent at 4.64 to $4.57 \mathrm{~m}$ depth (figure 7 ) and there is otherwise no variation in colour or texture of the sediments (Schiebel and Litt, 2017).

As this sediment sequence shows no evidence for full desiccation (e.g. desiccation cracks or crusts) of the lake during the past 10,000 years (Langgut et al., 2015), it can be assumed that sedimentation is continuous in the deepest parts of the Kinneret basin. The $17.8 \mathrm{~m}$ composite sequence covers approximately the last 9,000 cal yrs BP (figure 2, Schiebel and Litt, 2017). The age-depth model, which is presented in full detail in Schiebel and Litt (2017), relies on radiocarbon determinations on bulk organic material $(n=21)$, and selective encountered 
terrestrial macrofossils $(n=10)$. Age determinations on both materials at the same stratigraphic depth show that bulk organic ages are subject to a reservoir offset ranging from ca. 800 to ca. 1,600 years. The linear age-depth model (figure 2) assumes a constant sedimentation rate of $1.9 \mathrm{~mm} / \mathrm{year}$ for the Holocene and a gradual decrease of the reservoir offset from the beginning of the Holocene until present day, at a rate of ca. 70 years offset per 500 years (or 0.14 per year).

[insert figure 2]

\section{Diatom and other micropalaeontological analyses}

For diatom analysis 165 samples were taken at $10 \mathrm{~cm}$ intervals, corresponding to a resolution of ca. 50 years. Sample resolution was increased to $2 \mathrm{~cm}(10 \mathrm{yrs})$ or $5 \mathrm{~cm}$ ( $25 \mathrm{yrs})$ in two sections: $17.8-14.8 \mathrm{~m}$ and 4.6-3.5 $\mathrm{m}$, intervals in which the diatom concentration was low or a complete turnover of the diatom community was recognized. All samples were prepared using standard techniques (Battarbee, 1986): $0.2 \mathrm{~g}$ of wet sediment was treated with $\mathrm{H}_{2} \mathrm{O}_{2}(30 \%)$ and heated on a hotplate for several hours to oxidize organic matter. Afterwards a few drops of concentrated $\mathrm{HCl}(35 \%)$ were added to the hot sample residual to remove carbonates. Samples were washed with distilled water and centrifuged several times (1200 rpm for $7 \mathrm{~min}$ ) to eliminate the acid residual and avoid dissolution during storage. Known quantities of microspheres were added to allow the calculation of diatom concentrations (valves/g) for each sample. Subsamples from the cleaned, organic-free material were mounted in Naphrax ${ }^{\mathrm{TM}}$. Where diatoms were well preserved, more than 500 valves were counted using a Zeiss Axio Lab.A1 or an Olympus BX51 light microscope (LM) at x1000 magnification. In some samples, counts were lower (up to 200 valves) due to preservation problems or the complete lack of diatoms. Phytoliths were counted at a similar sample resolution in relative abundance to diatom counting. Diatom taxonomy and nomenclature follow Krammer and Lange-Bertalot (1986, 1988, 1991a, 1991b), Lange-Bertalot (2013) and the Diatom Flora of Israel (Ehrlich, 
1995). Following several authors (Cruces et al., 2010, Hobbs et al., 2011, Zhang et al., 2014) Stephanodiscus minutulus (KüTZING) Cleve \& MölleR and S. parvus StOERMER \& HÅKANSSON are merged into $S$. minutulus/parvus. Current changes in nomenclature are applied following the Catalogue of Diatom Names (Fourtanier and Kociolek, 2009). Diatom counts were converted to percentage data and displayed stratigraphically using Tilia, version 1.7.16 $\left({ }^{\odot} 1991-2011\right.$ Eric C. Grimm). Stratigraphically constrained cluster analysis using square root transformation was applied using CONISS (Grimm, 1987) to define zone boundaries, based on taxa present at $>5 \%$ abundance.

Palynological data from pollen analysis of 73 samples (parallel sampling depth to diatom samples) at a resolution of $25 \mathrm{~cm}(150 / \mathrm{yrs})$ is published in detail in Schiebel (2013, Schiebel and Litt, 2017).

The application of a transfer function to reconstruct lake-water nutrient concentrations from the taxonomic composition of diatom communities was not appropriate. The dominant taxon Cyclotella ocellata, has an extremely broad tolerance for nutrient availability (Fritz et al., 1993, van Dam et al., 1994, Kiss et al., 1996, Schlegel and Scheffler, 1999, Cremer and Wagner, 2003, Houk et al., 2010), and another common taxon, C. paleo-ocellata, is newly described (Vossel et al., 2015) and without a modern analogue.

\section{Diatom-based lake-level reconstruction}

Diatom-based lake-level reconstruction is based on the assumption that the variability in the ratio of planktonic to benthic $(\mathrm{P} / \mathrm{B})$ diatom taxa can be interpreted as a response to varying basin morphology as lake level fluctuates (Jones et al., 2013). As a lake shallows, benthic habitats may increasingly disperse into regions that were previously inhabited by planktonic diatoms living in a deeper water column, thereby changing the P/B-ratio. Effectively, decreasing lake level shortens the transport distance from littoral habitats to the deepest region 
of the lake (the favoured coring site), coupled with a reduction in area suitably deep for planktonic diatoms (Stone and Fritz, 2004). The plankton/benthos-ratio may also be affected by shifts in productivity. Therefore supporting evidence for lake-level change, coupled with regional shifts in moisture availability, is sought from the comparison with known palynological datasets and climate models as well as speleothem data from other study sites. Known trophic preferences of diatom taxa and the geochemistry data can help to disentangle if changes in the diatom assemblage reflect fluctuating lake-level conditions or are the result of productivity shifts.

The ratio of planktonic to benthic diatoms was calculated using the following formula provided by Wang et al. (2013):

$$
\frac{P}{B}=\frac{\sum(\text { planktonic taxa })}{\sum(\text { planktonic }+ \text { benthic taxa })}
$$

Following the allocation of Pollingher et al. (1984), facultative planktonic taxa such as Pseudostaurosira brevistriata, Staurosira venter and Staurosirella pinnata and epiphytic species such as Cocconeis spp. were assigned as benthic (i.e. littoral) taxa in this calculation.

\section{Geochemistry and Mineralogy}

Geochemistry was determined by non-destructive high resolution $(1 \mathrm{~cm})$ XRF core scanning (Itrax, Cox Analytical Systems, Sweden) at the University of Cologne, equipped with a Cr Xray source, operated under the following conditions: voltage $(\mathrm{kV}): 30$, current $(\mathrm{mA}): 30$ and exposure time (s): 10 .

For mineral analysis 50 samples were taken from various depths (approx. intervals of 20-30 $\mathrm{cm}$ ) in parallel with palaeoecological samples. Mineralogy was obtained from the powdered bulk fraction measured with a Siemens D5000, equipped with a $\mathrm{CuK} \alpha 1,2$ target tube. 
Operation conditions were: voltage $(\mathrm{kV})$ : 40, current $(\mathrm{mA}): 30$, scan range ( ${ }^{\circ} 2$ Theta):4-70, step-size $\left({ }^{\circ}\right.$ 2Theta): 0.02 , counting time $(\mathrm{s}): 1$, divergence slit $\left(^{\circ}\right): 1$, anti-scatter slit $\left(^{\circ}\right): 1$, mask (mm):15. Mineral assemblage was identified using the software, MacDiff (Petschick et al., 1996) and X'Pert High Score Plus (PANanlytical B.V.). The Rietveld refinement was applied using Profex v. 3.10.2 (Döbelin and Kleeberg, 2015) with additional structure files from the American Mineralogist Crystal Structure Database (Angel et al., 1990, Bailey, 1969, Maslen et al., 1995). Compositional data analysis was applied to the geochemical data (Aitchison, 2003, Comas-Cufí and Thió-Henestrosa, 2011) and gives further insights to the inter-element and possible source relationship (Aitchison and Greenacre, 2002). Biplots of complex data-sets can be used as a simple tool to investigate the structure of these data-sets (Greenacre, 2010).

\section{Results}

\section{Diatom analysis}

A total of 143 diatom taxa were identified within the subfossil sediment sequence of Lake Kinneret, most of which can be classified as oligohalobous-indifferent, requiring alkaline water for optimal growth (Krammer and Lange-Bertalot, 1986, 1988, 1991a, 1991b, Ehrlich, 1995, Lange-Bertalot, 2013). The summary diagram (figure 3) shows that diatoms were well preserved in most samples. They were rare (valves dissolving and fragmented) in two intervals (17.8-16.9 m; 15.4-14.8 $\mathrm{m}$ depth) and absent in one sample (4.57 $\mathrm{m}$ depth).

Planktonic taxa from the genera Cyclotella, Stephanodiscus and Aulacoseira dominate the sequence. Small, facultative planktonic fragilarioid taxa (e.g. Pseudostaurosira brevistriata, Staurosira venter, Staurosirella pinnata) are also common. Salt-tolerant diatom species such as Amphora coffeaeformis are present sporadically at low abundance. 
Four major diatom assemblage zones (DAZ-1-4) could be recognized from the results of CONISS (Grimm, 1987). Adopting the opposite of stratigraphic convention, zones in this study are numbered from the top down (DAZ-1 representing the recent past) to allow coherent sequencing of zone numbers in future studies of a longer sequence. A detailed description of each DAZ, its species composition and criteria for defining the lower zone boundaries are given in table 2. Although anthropogenic influences might have caused a shift in the modern diatom composition compared to the fossil one, the modern flora still contains many of the taxa present in the fossil record.

The P/B-ratio (given in figure 3, 5 and 6) shows some significant variations within the record, being particularly low within DAZ-4 and DAZ-2, which also exhibit low diatom concentration and high counts of phytoliths and high potassium values.

[insert table 2, insert figure 3]

\section{Sediment minero-geochemistry and compositional data analysis}

The major mineral assemblage of Lake Kinneret sediments is composed of calcite $\left[\mathrm{CaCO}_{3}\right]$, dolomite $\quad\left[\mathrm{CaMg}\left(\mathrm{CO}_{3}\right)_{2}\right], \quad$ quartz $\quad\left[\mathrm{SiO}_{2}\right], \quad$ muscovite/illite $\left[\left(\mathrm{K}, \mathrm{H}_{3} \mathrm{O}\right)(\mathrm{Al}, \mathrm{Mg}, \mathrm{Fe})_{2}(\mathrm{Si}, \mathrm{Al})_{4} \mathrm{O}_{10}\left[(\mathrm{OH})_{2},\left(\mathrm{H}_{2} \mathrm{O}\right)\right]\right.$ - probably in the fine fraction, and feldspars (plagioclase and alkali feldspar). In the diffractograms the feldspars were best explained by anorthite $\left[\mathrm{CaAl}_{2} \mathrm{Si}_{2} \mathrm{O}_{8}\right]$ and microcline $\left[\mathrm{KAlSi}_{3} \mathrm{O}_{8}\right]$. The structure that best resolved the phylossilicates was that of a muscovite, 2M1. The major mineral assemblage remained qualitatively constant throughout the sediment sequence and changes in abundance of the major minerals correlate well with diatom assemblage zone boundaries (table 3). Minerals in trace amounts occurred at specific depth, e.g. pyrite. Some of the diffractograms also show a carbonate mineral that was best defined by a rhodocrosite structure. Pyrite concentrations larger than $1 \%$ occurred particularly in DAZ-1, reaching up to $2.25 \mathrm{w} \%$. The rhodochrosite- 
like carbonate occurs sporadically in the profile at depths of $4.62 \mathrm{~m}(5.4 \mathrm{w} \%), 11.65 \mathrm{~m}(1.1$ w\%), $12.44 \mathrm{~m}(7.4 \mathrm{w} \%), 12.99 \mathrm{~m}(3.1 \mathrm{w} \%), 13.70 \mathrm{~m}(2.7 \mathrm{w} \%)$ and throughout DAZ-4 in concentrations of ca. $1.5 \mathrm{w} \%$.

From XRF-scanning, the elements $\mathrm{Si}, \mathrm{S}, \mathrm{Cl}, \mathrm{K}, \mathrm{Ca}, \mathrm{Ti}, \mathrm{Fe}$ and $\mathrm{Sr}$ were present at detectable concentrations, with reduced scattering throughout the profile; apart from sulphur and chlorine, these elements were also identified by mineralogy. In compositional data analysis, the biplot representation of the centered log ratio of the compositional data (clr-biplot) is the result of a single value decomposition under the consideration of composition nature of the data, and has properties relating to the pairs of variables, or geochemical elements (Aitchison and Greenacre, 2002). First observations from the clr-biplot show, that the defined diatom assemblage zones (DAZ) also have distinct geochemical fingerprints (figure 4).

For geochemical elements, the pair $[\mathrm{Ca}, \mathrm{Sr}]$ shows relatively small variance, as do the elements $[\mathrm{Fe}, \mathrm{Ti}, \mathrm{K}, \mathrm{Si}]$ between each other. Hence, $\mathrm{Ca}$ and $\mathrm{Sr}$ represent the carbonate accumulation; and $\mathrm{Ti}, \mathrm{K}, \mathrm{Fe}$ and $\mathrm{Si}$, represent the detrital fraction. The high variance between any pair of variables from these two groups of variables arises from the fact that $\mathrm{Ca}$ and $\mathrm{Sr}$ in the Kinneret sediments are reflecting lake internal carbonate precipitation, whereas a detrital source for the carbonate input is of secondary order. The elements $\mathrm{Cl}$ and $\mathrm{S}$ show large variance compared to the other elements. The $\mathrm{S} / \mathrm{Ti}$ ratio plotted versus depth shows covariance with the $\mathrm{Ca} / \mathrm{Ti}$ ratio. Plotted against depth, the chlorine counts have the typical shape of a diffusion profile, but inverted compared to that usually observed in marine cores (K. Tachikawa, personal communication). This is an effect of a saline gradient from the relatively fresh lake water towards shallow brines known from the subsurface of Lake Kinneret (Katz and Nishri, 2013, Rimmer and Givati, 2014b). For following interpretations, one representative element was chosen for each group identified from the $c l r$-biplot (e.g. Ca representing carbonate accumulation; K represents detrital input).

[insert table 3; insert figure 4] 


\section{Sediment geochemistry and implications for palaeoenvironmental reconstruction}

In the sediments of Lake Kinneret, $\mathrm{Ca}$ is retained in the lattices of plagioclase, dolomite and calcite. The positive correlation between $\mathrm{Ca}$ /Ti-ratio and calcite/quartz (figure 5) indicates that the calcium accumulation in Lake Kinneret is mainly driven by calcite. Pelagic bed sediments from Lake Kinneret consist with up to $60 \%$ of calcite (table 1, Serruya, 1978, Dubowski et al., 2003), that is mostly of autochthonous origin (Katz and Nishri, 2013). This chemical precipitation of calcite in the water column is a major process in the lake, favored by the waters' alkalinity and is associated to the lake mixing cycle (Katz and Nishri, 2013). The carbonate precipitation is strongly biogenic induced, as maximum calcite accumulation in the lake occurs between February and March due to intensive photosynthesis, occurring concomitant with bloom periods of the dinoflagellate Peridinium gatunense (Koren and Klein, 2000). The necessary carbonate and calcium ions are fed to the lake system in dissolved form from the catchment (Nishri and Stiller, 2014, Leng and Marshall, 2004) and picoplankton seems to serve as nuclei for calcite crystal growth (Nishri and Stiller, 2014). Thus, the primary carbonate accumulation is a potential indicator for lake productivity, given that carbonate precipitation from the water column of alkaline lakes is usually triggered by algal production and consequent changes in the carbonate equilibria (Ohlendorf and Sturm, 2001, Matter et al., 2010, Roeser et al., 2016).

Lake Kinneret data (figure 5) show good correspondence between the diatom concentration, the carbonate accumulation $(\mathrm{Ca} / \mathrm{Ti})$ and the sulphur accumulation $(\mathrm{S} / \mathrm{Ti})$. Additionally, the clr-biplot (figure 4) indicates that detrital sources of $\mathrm{Ca}$ are only of secondary importance. Lacustrine processes participating in sulphur cycling are largely biogeochemical such that sulphur is added to the sediments (a) as organic compounds or (b) dissolved sulphate that might be reduced to sulphides (Berner, 1971, Mackereth, 1966). Thus sulphur might indicate 
primary organic production or diagenetic processes. In summary, the correlation between the four parameters diatom concentration, $\mathrm{Ca} / \mathrm{Ti}$, calcite/quartz and $\mathrm{S} / \mathrm{Ti}$ suggests that they mainly reflect internal lake processes and together are indicative of lake productivity.

The detrital (clastic) input from the catchment is well reflected in the clr-biplot from the low variation between the elements $\mathrm{Si}, \mathrm{K}, \mathrm{Fe}$, Ti. From these elements, variations in potassium (K) counts are positively correlated to the sum of minerals representing the clastic fraction (quartz+feldspars+clays) and the phytolith counts (see figure 5). The detrital input can increase: (a) with enhanced humidity/rainfall, (b) with a lower lake level due to:(1) a reduction in lake water volume also reduces internal biomass and calcium production, which can cause a relative increase in detrital material, and (2) because a shallow lake exposes sediment surfaces in shallower littoral zones; (c) with open vegetation cover on the surrounding landscape, which increases sediment and nutrient input to the lake system, whereas a dense vegetation cover stabilizes the soil.

[insert figure 5]

\section{Discussion:}

In the following sections we discuss major palaeolimnological and environmental changes inferred from diatom analysis and minero-geochemistry data of a $17.8 \mathrm{~m}$ long sediment sequence of Lake Kinneret. The study spans the last 9,000 cal yrs BP and emphasis is given to disentangling climate-driven lake-level variation from shifts in trophic status and the impact of past human activities. A summary multi-proxy diagram is provided in figure 5 for a comparison of key limnological indicators and selected previously-published palynological data (Schiebel, 2013, Schiebel and Litt, 2017, Langgut et al., 2013, 2015, 2016). For interpretation of regional trends in moisture availability, a comparison of existing Holocene lake-level reconstructions from the Dead Sea (Kushnir and Stein, 2010) and Lake Kinneret 
(Hazan et al., 2005) are given in figure 6. The sparse occurance of obligate halophilous diatom taxa (e.g. Amphora coffeaeformis) indicates an essentially freshwater lake and a hydrologically open lacustrine system throughout the Holocene. Palaeolimnological interpretation and implications for palaeoclimate reconstruction are discussed according to diatom assemblage zone boundaries below. Calibrated ages are provided (according to the age-depth model given in figure 2; Schiebel and Litt, 2017), with associated archaeological periods for comparison with the wider literature.

[insert figure 6]

\section{Holocene history of Lake Kinneret - a multi-proxy interpretation:}

\section{From 9,000 - 7,400 cal yrs BP (DAZ-4, Pottery Neolithic Period)}

At the base of the sequence, diatom assemblage zone (DAZ) 4 is characterized by very low diatom concentration or even an absence of diatoms (figure 3), in subzones DAZ-4c and DAZ-4a in particular. The low diatom concentration may (1) result from poor preservation rather than being a reliable indicator of lake productivity (Battarbee et al., 2001), as many valves were broken or showed early signs of dissolution and/or (2) reflect an increased sediment accumulation rate in a phase of shallowing and sediment in-wash.

Where diatoms were identifiable, the diatom community of subzone DAZ-4c (9.1-8.6 cal yrs BP; table 2) includes only few planktonic Aulacoseira ambigua and Cyclotella spp., and is dominated by the robust facultative planktonic species, Pseudostaurosira brevistriata, Staurosira venter and Staurosirella pinnata, and fragmented valves of benthic genera such as Cocconeis (which often grow on submerged water plants growing in the littoral zone), Navicula and Nitzschia. As fragilarioid species are associated with environmental stress and physical disturbance (Schmidt et al., 2004), the high proportion of benthic and facultative planktonic taxa, can be linked with an expansion of the littoral zone, i.e. are a strong indicator 
for relatively shallow waters (Barker et al., 1994). The occurrence of Aulacoseira spp. in these subzones, and low abundance of Cyclotella ocellata, can be indicative of turbulent mixing of the water column and a temporary breakdown of stratification (Owen and Crossley, 1992, Anderson, 2000), since Aulacoseira have highly silicified valves and require a turbulent water column to stay within the photic zone. A combination of low lake level and high wind exposure can provide the turbulent, high nutrient condition favoured by this genus (Wolin and Stone, 2010). Shallow and turbulent water conditions can often enhance dissolution of diatom valves (Flower, 1993), which is here well reflected in the low diatom concentration.

Mineralogical and geochemical data indicate a phase of long-lasting and high detrital input, supported by palynological data: The poorest diatom preservation (DAZ-4c and DAZ-4a) occurs in phases of maximum inferred detrital input (increased potassium (K) counts, phytolith counts and detrital mineral concentrations with values up to $50 \mathrm{w} \%$ (clays+feldspars+quartz), and the unique presence of anorthite and microcline only in this sediment unit. DAZ-4 as a whole shows maximum abundance of steppic pollen taxa, indicating an natural open vegetation cover (not influenced by human activities) and arid climate conditions in the catchment area (figure 5, Schiebel and Litt, 2017). The open steppe vegetation would also favour soil erosion processes_(Zuazo and Pleguezuelo, 2008) and increase the sediment discharge, serving to dilute the diatom concentration. A high sediment discharge into the lake likely causes a turbid water column, limiting the light availability for the photosynthetic processes necessary for diatom growth, especially for species with a planktonic life habit. In addition, Barker et al. (1994) stated that planktonic diatom taxa can be restricted by turbidity during phases of enhanced catchment erosion. Tychoplanktonic fragilarioid species, which here occur at their peak abundance (table 2; figure 3), would be favoured by a turbid, sediment-loaded water column. The inferred phase of shallow lake levels for Lake Kinneret until ca. 8,600 cal yrs BP is consistent with pollen-climate model 
reconstructions from the Dead Sea (Litt et al., 2012), which document an arid (precipitation values $<350 \mathrm{~mm} / \mathrm{a}$ ) and warm period.

In subzone DAZ-4b, the shift towards dominance of the planktonic Cyclotella ocellatacomplex (45-75\%, table 2), i.e. Cyclotella ocellata and C. paleo-ocellata, suggests a slight increase in lake levels around 8,600 cal yrs BP lasting till 7,900 cal yrs BP. Total diatom concentration and the $\mathrm{Ca} / \mathrm{Ti}$-ratio remains low in spite of better diatom preservation, indicating reduced lacustrine productivity. As Cyclotella ocellata is known for its extremely broad tolerance for nutrient availability (Fritz et al., 1993, van Dam et al., 1994, Kiss et al., 1996, Schlegel and Scheffler, 1999, Cremer and Wagner, 2003, Houk et al., 2010), the cooccurrence of C. ocellata with C. paleo-ocellata is interpreted in this record as an indicator of oligotrophic conditions in a deeper open-lake system (Vossel et al., 2015, and references therein). Notably, the peak in the S/Ti-ratio at the beginning of DAZ-4b ( 8.6 cal yrs BP) differs from the $\mathrm{Ca} / \mathrm{Ti}$ signature, possibly indicating changes in lacustrine mixing related to a deeper water column. This can result as a transient state after a rapid lake-level increase, as known for other east Mediterranean lakes (e.g. Lake Van, Turkey; (Kaden et al., 2010)). An excursion towards more humid climate conditions with higher precipitation values is recognized between 8,600 to 7,900 cal yrs BP from speleothem records of the nearby Soreq cave, Israel (Bar-Matthews et al., 2000) and Jeita cave, Lebanon (Verheyden et al., 2008) with reconstructed precipitation values up to $550-700 \mathrm{~mm} / \mathrm{a}$. These shifts in moisture availability also affected the Eastern Mediterranean basin, as seen by the formation of sapropel (Kallel et al., 1997, De Rijk et al., 1999). Our data are strongly in accord with the hypothesis of a humid early Holocene in the southern Levant, clarifying the uncertainty generated previously by low lake levels reported in the Dead Sea (Kushnir and Stein, 2010). A slight rise in Dead Sea lake level does occur at this time (figure 6), reflecting a subdued response or local variation in climate. 
As noted above, conditions in subzone DAZ-4a $(7,900-7,400$ cal yrs BP) return to a relatively arid state with a low lake-level similar to that reported for DAZ-4c, even though diatom communities show higher relative abundance of fragilarioid and Cocconeis spp. rather than a diversity of benthic taxa, indicative of an unstable, fluctuating environment (table 2). Although later, according to the age-depth model (figure 2), it is within the error range (a reservoir effect of nearly 1,000 years; Schiebel and Litt, 2017) to argue that this subzone represents the Early to mid-Holocene boundary, coinciding with the so-called $8.2 \mathrm{k}$ yrs abrupt climate event (Walker et al., 2012). The $8.2 \mathrm{k}$ yrs cold (arid) event is the most prominent rapid climate change (RCC) at northern high latitudes during the Holocene (Johnsen et al., 2001, Pross et al., 2009) and its influence on terrestrial records in the Eastern Mediterranean is strongly debated (Robinson et al., 2006). The observed strong diatom response also occurs in some other Mediterranean sites (e.g. Cvetkoska et al., 2014, Ariztegui et al., 2001); here, other proxy data also show a peak, e.g. $\mathrm{K}$ - indicative for enhanced erosion, but no marked shift in palynological evidence for its impact on catchment vegetation is recognizable. BarMatthews et al. (1999) reported a sudden cooling and decrease in precipitation around $8.2 \mathrm{k}$ cal yrs BP for the Soreq cave (Israel). Moreover, geomorphological lake-level reconstructions from Lake Kinneret (Hazan et al., 2005, and this study) and the Dead Sea (Kushnir and Stein, 2010, Litt et al., 2012) show low lake-level stands between 8,000-7,500 cal yrs BP (figure 6), indicating a region-wide response to shifts in moisture towards more arid climate conditions. Kushnir and Stein (2010) conclude that marked Holocene arid events, which are expressed as abrupt and relatively large drops in the Dead Sea lake level (10 m or more), correlate with pronounced cooling episodes recorded in Eastern Mediterranean winter sea surface temperatures (SST, reconstructed from planktonic foraminifera in marine sediment cores) and with cold events in northern latitudes. 
From 7,400 - 2,200 cal yrs BP (DAZ-3, Transition Neolithic/Chalcolithic Period - Bronze Age-Iron Age)

DAZ-3 is characterized by the consistently high abundance of planktonic diatom taxa (> 80\%) mainly belonging to the Cyclotella ocellata-complex (table 2), indicating stable, high lake levels and an oligo-mesotrophic state throughout this subzone (Vossel et al., 2015, and references therein). The marked transition to plankton dominance represents strong evidence for a rapid increase in lake level around 7,400 cal yrs BP, which is also observed in the diatom data from Lake Prespa, further north (Cvetkoska et al., 2014).

From a geochemical perspective, in phase primary carbonate accumulation $(\mathrm{Ca} / \mathrm{Ti}$-ratio) and diatom concentration indicate long-lasting increased productivity phases between 6,000 and 5,000 cal yrs BP and between 4,000 and 2,200 cal yrs BP (figure 4). In general, DAZ-3 is a phase of moderate detrital input. Abrupt, marked excursions of potassium also occur, indicating pulses of terrigenous input, which might be caused by flood events or other external triggers. Most of the punctual increases in detrital input have no influence on the diatom flora.

The interpretation of enhanced humidity is supported by palynological evidence for an increase of summer-green oak (Quercus ithaburensis-type), especially in subzone DAZ-3a and a slight decrease in steppic vegetation, which seems to be natural and not anthropogenically induced (Schiebel and Litt, 2017). The pollen evidence alone was not definitive since the climate signal is strongly overprinted by human activities from the Chalcolithic period onwards. Fluctuating human settlement size and activities around Lake Kinneret during this time period (Langgut et al., 2013, 2015) seem not to have a remarkable effect on the lake's ecosystem and trophic state, as interpreted from the high-resolution diatom record.

In summary, all analysed proxies indicate a stable, oligo-mesotrophic lake system for the midHolocene with a maximum lake-level high-stand lasting from 7,500 till 2,200 yrs cal BP. This 
is in accord with climate models based on palynological data, providing evidence for an extended humid phase with precipitation values up to $650 \mathrm{~mm} / \mathrm{a}$ for the Levantine region (Litt et al., 2012). Additionally, our dataset is in accord with other diatom records in the Eastern Mediterranean, which also exhibit an inferred mid-Holocene phase of maximum lake levels (e.g. Lake Ioannina; (Jones et al., 2013); Lake Prespa (Cvetkoska et al., 2014) and Lake Dojran (Zhang et al., 2014)). A mid-humid Holocene is also documented by increasing lake levels in Lake Iznik based on high resolution grain size analysis and carbonate accumulation (Roeser et al., 2016). Many localities in the Levant support the hypothesis of a humid climate optimum, e.g. speleothem records from Soreq cave, Israel (Bar-Matthews and Ayalon, 2011) and Jeita cave, Lebanon (Verheyden et al., 2008) and a new, high-resolution pollen record from Lake Kinneret (Langgut et al., 2016).

Previous lake-level reconstructions for Lake Kinneret (Hazan et al., 2005) and the Dead Sea (Kushnir and Stein, 2010) (figure 6) had shown inconsistencies, which were thought to reflect differences in patterns of evaporation and local differences in freshwater supply (Stein, 2014). From our results, the stability of the Kinneret high stand accentuates the apparent discrepancy further, standing in stark contrast to the major fluctuations in lake level inferred for the Dead Sea. Although our results are more closely in accord with other records of the region, it is possible that, as a closed-lake basin, the Dead Sea exhibits far higher sensitivity to changing moisture availability. Furthermore, our results support the hypothesis that the strong north to south climate gradient of today (see also site description section) operated through most of the Holocene, which might explain independent changes in the limnological behaviour of the two lake systems. These observations support the analysis of Enzel et al. (2008), who argued that the present north-south climatic gradients between arid and Mediterranean zones were already established during the Late Pleistocene. 
The diatom record of Lake Kinneret shows, in contrast to the 8.2 event, no evidence for the so-called 4.2 cal kyr BP drought event appearing across the Northern Hemisphere between 4.2-3.8 k cal yrs BP (Mayewski et al., 2004). The lack of response might be caused by the fact that the lake was a deep, stable ecosystem during this time. A similar lack of diatom response was observed in Lake Prespa (Cvetkoska et al., 2014). Nevertheless, there is subtle evidence in the pollen record (Schiebel and Litt, 2017) comprising decreased arboreal pollen percentages around 4,000 cal yrs BP (figure 4).

During the late Bronze Age (around 3,200 cal yrs BP) a subsequent pronounced dry episode has been identified from palynological analysis of Lake Kinneret (Langgut et al., 2013, 2015, Schiebel and Litt, 2017). This event lasted probably slightly more than a century and is represented by a reduction in arboreal pollen percentages (low Quercus spp. in figure 5), clearly not induced by human deforestation as settlement activity was low in many areas during that time. Again, the stable, deep lake-level state in Kinneret during this phase might cause a buffering effect on the diatom response, possibly similar to observations made in Lake Eski Acigöl, Turkey (Roberts et al., 2001). A remarkable drop in lake levels does appear to occur in the Dead Sea at this time (Kushnir and Stein, 2010, Stein et al., 2010), however.

\section{Sediment disturbance at 2.3 k cal yrs BP}

In the rather homogenous Holocene sediment sequence of Lake Kinneret, a major shift in palaeolimnological proxy data at 4.64 to $4.57 \mathrm{~m}$ depth (ca. 2.3 cal $\mathrm{k}$ yrs BP; figure 7), indicates the occurrence of an event layer. This $4 \mathrm{~cm}$ thick sediment sequence shows abrupt lithologic and mineralogical boundaries, and grain size shows inverse grading, which is indicative of a rapid depositional event. Concentrations of microcline, detrital dolomite and quartz are the highest of the profile and potassium and phytolith counts exhibit clear peaks.

This distal deposit of a turbidity current/gravity flow might have originated from two distinct natural triggers (a) seismic activity or (b) climate, as a result of a flash flood event. Terrestrial 
deposits of paleo-earthquakes with Holocene age are encountered at the south-eastern margin of Lake Kinneret (e.g. Klinger et al., 2015, Reches and Hoexter, 1981). Given the lake's location on the active Dead Sea transform fault system, it is conceivable that the observed event layer originated from a seismic event. On the other hand, deposits of flood events are known from Lake Kinneret, however appearing closer to the shore and under direct influence of river discharge. For example, Williams (2016) recently recorded two flood deposits in a short sediment core ( $143 \mathrm{~cm} ; 4,000$ years) from the western shore of Lake Kinneret, providing strong evidence for fluctuating dry-wet conditions of the Roman-Byzantine periods due to climate instability.

Another possible human-induced explanation for the sediment disturbance could be the start of olive tree cultivation and the previous clearance of the natural vegetation visible in the gradual decrease of Quercus spp. in the pollen data (Schiebel and Litt, 2017) at the top of DAZ-3a. Natural vegetation clearance and heavy rain could cause a rapid in-wash of soils and nutrients from the catchment (Cohen, 2003, Zuazo and Pleguezuelo, 2008), which also would explain high amounts of $\mathrm{K}$ and detrital minerals, low lake productivity (i.e. low diatom concentration and $\mathrm{Ca} / \mathrm{Ti}$ ratio), as well as the sample devoid of diatoms. Further research is necessary to identify the causal mechanism, but the event is followed shortly afterwards by a complete compositional change of the diatom community towards a more eutrophic assemblage. [insert figure 7]

\section{From 2,200 -1,600 cal yrs BP (DAZ-2, Hellenistic \& Roman/Byzantine Period)}

The onset of DAZ-2 (corresponding to the Hellenistic Period; around 2,200 cal yrs BP) is marked by a major reduction in the P/B-ratio and diatom concentration. A floral shift towards planktonic taxa such as Aulacoseira granulata, Cyclotella polymorpha and small Stephanodiscus (S. minutulus/parvus and S. hantzschii) strongly indicate a higher trophic 
state of the lake (Krammer and Lange-Bertalot, 1986, 1991a, 1988, 1991b, Stiller et al., 1984) and a possible reduction of lake level. Cyclotella paleo-ocellata and S. galileensis disappear completely from the record probably due to the increase in nutrient availability. Pollingher et al. (1984) made similar observations in diatom analysis of the sediment core KIND-4, taken close to station D in the southern part of Lake Kinneret at $23 \mathrm{~m}$ water depth, and inferred nutrient enrichment correlated to more dense human settlement and intensive agricultural activity around the lake during the Hellenistic-Roman period. The increase and diversification of Pediastrum spp. in this DAZ also supports an increase in trophic state (Pollingher, 1986). The surprisingly low diatom concentration in DAZ-2 may be explained by the competitive advantage of green algae over diatoms (Stiller et al., 1984).

This interpretation is supported by the replacement of oak woodland by olive plantations (Olea europaea) in the catchment (Schiebel and Litt, 2017) and an inferred increase in terrigenous input indicated by mineralogy and phytolith data. Neumann et al. (2007) recognized deforestation activities during the same period in nearby Birkat Ram, a small maar lake in the northern Golan Heights. Rising population density, bigger urban societies and continuous agriculture activities are also well documented archaeologically in the Hellenistic and Roman/Byzantine time periods (Anderson, 1995, Dar, 1993, Chancey and Porter, 2001). The clearance of the surrounding natural vegetation would enhance erosion of nutrients and terrestrial input to the lake, indicating that the shift from an oligotrophic to a more meso- to eutrophic lake system was induced by human activities rather than climate change.

Deforestation and intensive farming has led to marked changes in the nutrient balance of many lake systems during the mid to late Holocene, which is well reflected in many palaeolimnological records based on diatoms around the Mediterranean (e.g. Cvetkoska et al., 2014, Zhang et al., 2014).

The evidence for lake-level shallowing in the proxy data (slightly comparable to DAZ-4a/c) may be climatically induced, since this has also been recognised as a more arid, warmer phase 
by other researchers (Finné et al., 2011), but standing in contrast to colder and humid climate conditions reported for this region (Issar, 2003). A climate-induced shallower lake-level phase in Lake Kinneret is therefore unlikely and also stands in contrast to a high lake-level stand reported from the Dead Sea (figure 6, Kushnir and Stein, 2010). Woodbridge and Roberts (2011) have demonstrated in a palaeoclimate record from Nar Lake (Turkey) that anthropogenic changes in land use can lead to long-term shifts in the diatom response to climate variability through time and therefore highlight that diatom-inferred climate interpretations on Late Quaternary timescales should be considered with caution.

An alternative, non-climatically induced explanation for a lake-level reduction of Lake Kinneret could be human water abstraction associated with catchment vegetation management and irrigation. Major irrigation systems were introduced to this region in Hellenistic times and become common in the Roman era to ensure water-supply of bigger urban centres (Lemche, 2015), such as Tiberias, which were founded in the Roman period.

Overall, it can be concluded that human activities are strongly overprinting the climate signal of the multi-proxy record after the onset of the Hellenistic/Roman period. Shifts in the diatom assemblage or varying P/B-ratios in the following sections therefore reflect changes in the trophic state of the lake and its productivity, rather than being a reliable indicator for fluctuating lake levels.

\section{From 1,600 - 900 cal yrs BP (DAZ-1c/-1b, Late Byzantine \& Islamic Period)}

In DAZ-1c/-1b the recovery to an oligo-mesotrophic lake system is indicated by a decrease of initial dominance of $C$. polymorpha (DAZ-1c; mesotrophic) and the subsequent renewed dominance of $C$. ocellata ( $<80 \%$; oligo-mesotrophic) in this subzone. The low abundance of Aulacoseira and Stephanodiscus taxa also support a shift to more oligo-mesotrophic conditions. This is not reflected in the geochemical data. Carbonate accumulation and S/Ti 
both increase, whereas detrital minerals are at their lowest values $(<15 \%)$. The consistent increase of pyrite concentration is indicative of an at least seasonally anoxic sediment surface, likely allowing sin-depositional pyrite concentration. This is a typical feature in eutrophic lakes, when increases in TOC production, and especially consumption, lead to anoxic conditions in the lower water column, resulting in a stratified system.Schiebel and Litt (2017, Schiebel, 2013) report a period of woodland regeneration with the re-occupation of abandoned olive groves by evergreen oaks and pistachios in the palynological record of Lake Kinneret in this period. The recovery of the diatom flora as well as the regeneration of natural woodland can be reflecting a decrease in settlement activities and in economic structures as well as a decline of agriculture and population density reported in the Southern Levant during the Islamic Period (Safrai, 1994).

\section{From 900 cal yrs BP-present (DAZ-1a, Crusader Period till today)}

DAZ-1a incorporates the species composition of the modern diatom flora of Lake Kinneret, which is now strongly influenced by the economic revival in this area, especially the development of industry and tourism. The subzone DAZ-1a is dominated by strongly eutrophic diatom taxa, which are also tolerant of general water pollution, including Aulacoseira granulata, Cyclotella meneghiniana and large Fragilaria capucina (Krammer and Lange-Bertalot, 1986, 1988, 1991a, 1991b, Ehrlich, 1995, Lange-Bertalot, 2013). As noted above, the low diatom concentration in the modern flora is probably due to a marked increase in dominance of dinoflagellates and green algae (Pyrrhophyta-Chlorophyta assemblages) in the phytoplankton (Pollingher et al., 1984). The geochemical data exhibit an increase in detrital values and maximum pyrite values. The lack of shifts in other indicators compared to DAZ-1b suggest, that it was only recently that the annual pattern of lake mixing was established. This is also supported by the laminated sediment deposits only occurring in the upper most $25 \mathrm{~cm}$ of the sediment sequence. 
Lake levels fluctuated markedly from 1,600 cal yrs BP until present, as indicated by shifts both in diatom concentration and the P/B-ratio. As noted above, lake levels can fluctuate by up to $4 \mathrm{~m}$ per year depending on precipitation/evaporation, but mostly on human water management control. Human-induced impacts (e.g. water abstraction, industry and agriculture) on the lake ecosystem and its watershed are well documented over the last $>40$ years by the Lake Kinneret monitoring program (Sukenik et al., 2014).

\section{Conclusions:}

Our study has greatly improved our understanding of Holocene climate variability in the Lake Kinneret area and across the southern Levant as a whole. The diatom data in particular provide a robust signal of lake-level response to shifts in moisture availability, although partly obscured in the later record by the impact of human activities. In the context of understanding palaeoclimate variability our major conclusions are:

1. Apart from lithological evidence for a possible disturbance event around 2,300 cal yrs BP, the Lake Kinneret sediment record provides an important continuous highresolution Holocene sequence for the southern Levant.

2. Major shifts in the diatom community and especially in the P/B-ratio, during the Early and mid-Holocene are driven by changes in lake level and moisture availability rather than lake productivity or changes in trophic status.

3. During the Late Holocene, after 2,200 cal yrs BP, the climatic signal is overprinted by accelerated nutrient enrichment linked to intensification of human activities in the catchment area.

4. The new detailed lake-level reconstruction for Lake Kinneret based on the P/B-ratio of diatoms in combination with minero-geochemical analysis allows for the first time a detailed comparison between the two contrasting lake systems of the Dead Sea and Lake Kinneret. Following a phase of lake-level fluctuations in the Early Holocene 
linked to alternation between an arid and more humid climate in Lake Kinneret, diatoms indicate a prolonged stable deep lake phase throughout the mid-Holocene and the onset of the late Holocene due to long-lasting humid climate conditions. Independent changes in the limnlogical behaviour of Lake Kinneret and the Dead Sea probably reflect the long-term existence of the strong north (humid) to south (arid) climate gradient which operates today, coupled with the higher sensitivity to changing evaporation/precipitation conditions of the Dead Sea, as a closed basin system.

5. The presented diatom record shows similarities to palaeoclimate records studied around the Mediterranean. Lake ecosystems of these moderately deep, alkaline lakes seem to react in similar ways to larger scale climatic events during the Holocene such as the 8.2 event and the mid-Holocene humid period.

\section{Acknowledgements}

A part of this work (preliminary investigations) is based on the unpublished master thesis of Hannah Vossel carried out at the Steinmann Institute at the University of Bonn under the supervision of Thomas Litt and Georg Heumann. We would like to thank Vera Schiebel for providing palynological datasets and Andrea Miebach and Mordechai Stein for the critical discussion and comments. We also would like to thank Christoph Steinhoff and Helen Böttcher for preparing samples for further laboratory procedure. Last but not least, we would like to thank Georg Heumann, Sven Oliver Franz and Michael Köhler for their support during the coring campaign and two anonymous reviewers for the constructive comments on our manuscript.Funding

Part of this research, including the drilling campaign, was funded by the German Research Council (DFG) as part of the Collaborative Research Center CRC 806 "Our Way to Europe". Hannah Vossel got personal financial support from the German Academic Scholarship 
Foundation (Studienstiftung des deutschen Volkes). Patricia Roeser held a postdoctoral scholarship from the Brazilian National Council for Scientific and Technological Development - CNPq.

\section{References}

Aitchison J. (2003) The Statistical Analysis of Compositional Data The Blackburn Press. Aitchison J \& Greenacre M. (2002) Biplots of compositional data. Journal of the Royal Statistical Society: Series C (Applied Statistics) 51: 375-392.

Anderson J. (1995) The impact of Rome on the periphery: the case of Palestina-Roman period (63 BCE-324 CE). In: Levy TE (ed) The archaeology of society in the Holy Land, London. London: Leicester University Press, 624.

Anderson NJ. (2000) Miniview: diatoms, temperature and climatic change. European Journal of Phycology 35: 307-314.

Angel RJ, Carpenter MA \& Finger LW. (1990) Structural variation associated with compositional variation and order-disorder behavior in anorthite-rich feldspars. American Mineralogist 75 : 150-162.

Ariztegui D, Chondrogianni C, Lami A, Guilizzoni P \& Lafargue E. (2001) Lacustrine organic matter and the Holocene paleoenvironmental record of Lake Albano (central Italy). Journal of Paleolimnology 26: 283-292.

Bailey S. (1969) Refinement of an intermediate microcline structure. American Mineralogist 54: 15401545.

Bar-Matthews M \& Ayalon A. (2011) Mid-Holocene climate variations revealed by high-resolution speleothem records from Soreq Cave, Israel and their correlation with cultural changes. The Holocene 21: 163-171.

Bar-Matthews M, Ayalon A \& Kaufman A. (2000) Timing and hydrological conditions of Sapropel events in the Eastern Mediterranean, as evident from speleothems, Soreq cave, Israel. Chemical Geology 169: 145-156.

Bar-Matthews M, Ayalon A, Kaufman A \& Wasserburg GJ. (1999) The Eastern Mediterranean paleoclimate as a reflection of regional events: Soreq cave, Israel. Earth and Planetary Science Letters 166: 85-95.

Bar-Matthews M, Ayalon A, Vaks A \& Frumkin A. (2017) Climate and Environment Reconstructions based on Speleothems from the Levant. In: Enzel Y \& Bar-Yosef O (eds) Quaternary of the Levant - Environments, Climate Change, and Humans. Cambridge: Cambridge Universtiy Press, 151-164.

Barker P, Roberts N, Lamb H, Van der Kaars S \& Benkaddour A. (1994) Interpretation of Holocene lake-level change from diatom assemblages in Lake Sidi Ali, Middle Atlas, Morocco. Journal of Paleolimnology 12: 223-234.

Baruch U. (1986) The Late Holocene Vegetational History of Lake Kinneret (Sea of Galilee), Israel. Paléorient: 37-48.

Battarbee RW. (1986) Diatom analysis. In: E BB (ed) Handbook of Holocene Palaeoecology and Palaeohydology. New York: John Wiley \& Sons Ltd, 527-670.

Battarbee RW, Jones VJ, Flower RJ, Cameron NG, Bennion H, Carvalho L \& Juggins S. (2001) Diatoms. In: Smol JP, Briks HJB \& M LB (eds) Tracking Environmental Change Using Lake Sediments. Kluwer Academic Publishers, 155-204.

Berman T, Zohary T, Nishri A \& Sukenik A. (2014) General background. In: Zohary T, Sukenik A, Berman T \& Nishri A (eds) Lake Kinneret - Ecology and Managment. Dordrecht: Springer, 115. 
Berner RA. (1971) Principles of Chemical Sedimentology: McGraw-Hill Book Company.

Chancey MA \& Porter A. (2001) The Archaeology of Roman Palestine. Near Eastern Archaeology 64: 164-203.

Cohen AS. (2003) Paleolimnology: the history and evolution of lake systems, New York: Oxford University Press, USA.

Comas-Cufí M \& Thió-Henestrosa S. (2011) CoDaPack 2.0: a stand-alone, multi-platform compositional software. In: Egozcue JJ, Tolosana-Delgado R \& Ortego MI (eds) Proceedings of the 4th International Workshop on Compositional Data Analysis. 1-10.

Cremer H \& Wagner B. (2003) The diatom flora in the ultra-oligotrophic Lake El'gygytgyn, Chukotka. Polar Biology 26: 105-114.

Cruces F, Rivera P \& Urrutia R. (2010) Observations and comments on the diatom Stephanodiscus minutulus (Kützing) Cleve \& Möller (Bacillariophyceae) found for the first time in Chile from bottom sediments collected in Lake Laja. Gayana Botany 67: 12-18.

Cvetkoska A, Levkov Z, Reed JM \& Wagner B. (2014) Late Glacial to Holocene climate change and human impact in the Mediterranean: The last ca. 17 ka diatom record of Lake Prespa (Macedonia/Albania/Greece). Palaeogeography, Palaeoclimatology, Palaeoecology 406: 2232.

Dar S. (1993) Settlements and Cult Sites on Mount Hermon, Israel: Ituraean Culture in the Hellenistic and Roman Periods

De Rijk S, Hayes A \& Rohling EJ. (1999) Eastern Mediterranean sapropel S1 interruption: an expression of the onset of climatic deterioration around 7 ka BP. Marine Geology 153: 337343.

Döbelin N \& Kleeberg R. (2015) Profex: a graphical user interface for the Rietveld refinement program BGMN. Journal of applied crystallography 48: 1573-1580.

Dubowski Y, Erez J \& Stiller M. (2003) Isotopic paleolimnology of Lake Kinneret. Limnology and Oceanography 48: 68-78.

Ehrlich A. (1985) The eco-biostratigraphic significance of the fossil diatoms of Lake Kinneret. Geological Survey Israel Current Research 5: 24-30.

Ehrlich A. (1995) Atlas of the inland-water diatom flora of Israel, Jerusalem: Geological Survey of Israel; Israel Academy of Sciences and Humanities.

Enzel Y, Amit R, Dayan U, Crouvi O, Kahana R, Ziv B \& Sharon D. (2008) The climatic and physiographic controls of the eastern Mediterranean over the late Pleistocene climates in the southern Levant and its neighboring deserts. Global and Planetary Change 60: 165-192.

Finné M, Holmgren K, Sundqvist HS, Weiberg E \& Lindblom M. (2011) Climate in the eastern Mediterranean, and adjacent regions, during the past 6000 years $-A$ review. Journal of Archaeological Science 38: 3153-3173.

Flower RJ. (1993) Diatom preservation: experiments and observations on dissolution and breakage in modern and fossil material. Hydrobiologia 269 (270): 473-484.

Fourtanier E \& Kociolek JP. (2009) Catalogue of Diatom Names - Online Version. California Academy of Sciences, San Francisco.

Fritz S, Kingston J \& Engstrom D. (1993) Quantitative trophic reconstruction from sedimentary diatom assemblages: a cautionary tale. Freshwater biology 30: 1-23.

Frumkin A, Bar-Yosef O \& Schwarcz HP. (2011) Possible paleohydrologic and paleoclimatic effects on hominin migration and occupation of the Levantine Middle Paleolithic. Journal of Human Evolution 60: 437-451.

Gophen M. (2003) Water quality management in Lake Kinneret (Israel): hydrological and food web perspectives. Journal of limnology 62: 91-101.

Greenacre M. (2010) Biplots in Practice. Fundación BBVA, 240.

Grimm EC. (1987) CONISS: a FORTRAN 77 program for stratigraphically constrained cluster analysis by the method of incremental sum of squares. Computers \& Geosciences 13: 13-35. 
Hazan N, Stein M, Agnon A, Marco S, Nadel D, Negendank JFW, Schwab MJ \& Neev D. (2005) The late Quaternary limnological history of Lake Kinneret (Sea of Galilee), Israel. Quaternary Research 63: 60-77.

Hazan N, Stein M \& Marco S. (2004) Lake Kinneret levels and active faulting in the Tiberias area. Israel Journal of Earth Sciences 53 (3-4): 199-205.

Hobbs WO, Fritz SC, Stone JR, Donovan JJ, Grimm EC \& Almendinger JE. (2011) Environmental history of a closed-basin lake in the US Great Plains: Diatom response to variations in groundwater flow regimes over the last 8500 cal. yr BP. The Holocene 21: 1203-1216.

Houk V, Klee R \& Tanaka H. (2010) Atlas of freshwater centric diatoms with a brief key and descriptions Part III. Stephanodiscaceae A Cyclotella, Tertiarius, Discostella. In: Poulíčková A (ed). Olomouc: Fottea, 498.

Hurwitz S, Garfunkel Z, Ben-Gai Y, Reznikov M, Rotstein Y \& Gvirtzman H. (2002) The tectonic framework of a complex pull-apart basin: seismic reflection observations in the Sea of Galilee, Dead Sea transform. Tectonophysics 359: 289-306.

Issar A \& Zohar M. (2004) Climate Change-Environment and Civilization in the Middle East: Springer Science \& Business Media.

Issar AS. (2003) Climate changes in the Levant during the Late Quaternary Period. Climate changes during the Holocene and their impact on hydrological systems New York: Cambridge University Press, 1-30.

Johnsen SJ, Dahl-Jensen D, Gundestrup N, Steffensen JP, Clausen HB, Miller H, Masson-Delmotte V, Sveinbjörnsdottir AE \& White J. (2001) Oxygen isotope and palaeotemperature records from six Greenland ice-core stations: Camp Century, Dye-3, GRIP, GISP2, Renland and North GRIP. Journal of Quaternary Science 16: 299-307.

Jones TD, Lawson IT, Reed JM, Wilson GP, Leng MJ, Gierga M, Bernasconi SM, Smittenberg RH, Hajdas I, Bryant CL \& Tzedakis PC. (2013) Diatom-inferred late Pleistocene and Holocene palaeolimnological changes in the loannina basin, northwest Greece. Journal of Paleolimnology 49: 185-204.

Kaden H, Peeters F, Lorke A, Kipfer R, Tomonaga Y \& Karabiyikoglu M. (2010) Impact of lake level change on deep-water renewal and oxic conditions in deep saline Lake Van, Turkey. Water Resources Research 46.

Kallel N, Paterne M, Duplessy J, Vergnaudgrazzini C, Pujol C, Labeyrie L, Arnold M, Fontugne M \& Pierre C. (1997) Enhanced rainfall in the Mediterranean region during the last sapropel event. Oceanolica Acta 20: 697-712.

Katz A \& Nishri A. (2013) Calcium, magnesium and strontium cycling in stratified, hardwater lakes: Lake Kinneret (Sea of Galilee), Israel. Geochimica et Cosmochimica Acta 105: 372-394.

Kiss KT, Rojo C \& Alvarez Cobelas M. (1996) Morphological variability of a Cyclotella ocellata (Bacillariophyceae) population in the Lake Las Madres (Spain). Algological Studies: 37-55.

Klinger Y, Le Béon M \& Al-Qaryouti M. (2015) 5000 yr of paleoseismicity along the southern Dead Sea fault. Geophysical Journal International 202: 313-327.

Kolodny Y, Katz A, Starinsky A, Moise T \& Simon E. (1999) Chemical tracing of salinity sources in Lake Kinneret (Sea of Galilee), Israel. Limnology and Oceanography 44: 1035-1044.

Koren N \& Klein M. (2000) Rate of sedimentation in Lake Kinneret, Israel: spatial and temporal variations. Earth Surface Processes and Landforms 25: 895-904.

Krammer K \& Lange-Bertalot H. (1986) Bacillariophyceae. 1. Teil: Naviculaceae. In: Ettl H, Gerloff H, Heyning H \& Mollenhauer D (eds) Süßwasserflora von Mitteleuropa. Heidelberg: Spektrum Akademischer Verlag, 876.

Krammer K \& Lange-Bertalot H. (1988) Bacillariophyceae. 2. Teil: Bacillariaceae, Epithemiaceae, Surirellacea. Süßwasserflora von Mitteleuropa. In: Ettl H, Gerloff H, Heyning H \& Mollenhauer D (eds) Süßwasserflora von Mitteleuropa. Heidelberg: Spekrtum Akademischer Verlag, 611. 
Krammer K \& Lange-Bertalot H. (1991a) Bacillariophyceae. 3. Teil: Centrales, Fragilariaceae, Eunotiaceae. In: Ettl H, Gerloff H, Heyning H \& Mollenhauer D (eds) Süßwasserflora von Mitteleuropa. Heidelberg: Spektum Akademischer Verlag, 598.

Krammer K \& Lange-Bertalot H. (1991b) Bacillariophyceae. 4. Teil: Achnanthaceae-Kritische Ergänzungen zu Achnanthes s.I., Navicula s.str., Gomphonema. In: Ettl H, Gerloff H, Heyning H \& Mollenhauer D (eds) Süsswasserflora von Mitteleuropa. Heidelberg: Spektrum Akademischer Verlag 437.

Kushnir Y \& Stein M. (2010) North Atlantic influence on 19th-20th century rainfall in the Dead Sea watershed, teleconnections with the Sahel, and implication for Holocene climate fluctuations. Quaternary Science Reviews 29: 3843-3860.

Lange-Bertalot H. (2013) Diatomeen im Süßwasser-Benthos von Mitteleuropa, Königsstein: Koeltz Scientific Books.

Langgut D, Adams MJ \& Finkelstein I. (2016) Climate, settlement patterns and olive horticulture in the southern Levant during the Early Bronze and Intermediate Bronze Ages (c. 3600-1950 BC). Levant 48: 117-134.

Langgut D, Finkelstein I \& Litt T. (2013) Climate and the Late Bronze Collapse: New Evidence from the Southern Levant. Tel Aviv 40: 149-175.

Langgut D, Finkelstein I, Litt T, Neumann FH \& Stein M. (2015) Vegetation and Climate Changes during the Bronze and Iron Ages ( $3600-600$ BCE) in the Southern Levant Based on Palynological Records. Radiocarbon 57: 217-235.

Lemche NP. (2015) Ancient Israel: A new history of Israel, London: Bloomsbury Publishing.

Leng MJ \& Marshall JD. (2004) Palaeoclimate interpretation of stable isotope data from lake sediment archives. Quaternary Science Reviews 23: 811-831.

Lionello P, Malanotte-Rizzoli P, Boscolo R, Alpert P, Artale V, Li L, Luterbacher J, May W, Trigo R, Tsimplis M, Ulbrich U \& Xoplaki E. (2006) The Mediterranean climate: An overview of the main characteristics and issues. In: P. Lionello PM-R \& Boscolo R (eds) Developments in Earth and Environmental Sciences. Elsevier, 1-26.

Litt T \& Ohlwein C. (2017) Pollen as Palaeoclimate Indicators in the Levant. In: Enzel Y \& Bar-Yosef O (eds) Quaternary of the Levant - Environments, Climate Change, and Humans. Cambridge: Cambridge University Press, 337-345.

Litt T, Ohlwein C, Neumann FH, Hense A \& Stein M. (2012) Holocene climate variability in the Levant from the Dead Sea pollen record. Quaternary Science Reviews 49: 95-105.

Mackereth FJH. (1966) Some chemical observations on post-glacial lake sediments. Freshwater Biological Association 250: 165-213.

Maher LA, Banning EB \& Chazan M. (2011) Oasis or Mirage? Assessing the Role of Abrupt Climate Change in the Prehistory of the Southern Levant. Cambridge Archaeological Journal 21: 1-30.

Maslen E, Streltsov V, Streltsova N \& Ishizawa N. (1995) Electron density and optical anisotropy in rhombohedral carbonates. III. Synchrotron X-ray studies of $\mathrm{CaCO} 3, \mathrm{MgCO} 3$ and $\mathrm{MnCO}$. Acta Crystallographica Section B: Structural Science 51: 929-939.

Matter M, Anselmetti FS, Jordanoska B, Wagner B, Wessels M \& Wüest A. (2010) Carbonate sedimentation and effects of eutrophication observed at the Kališta subaquatic springs in Lake Ohrid (Macedonia). Biogeosciences 7: 3755-3767.

Mayewski PA, Rohling EE, Curt Stager J, Karlén W, Maasch KA, David Meeker L, Meyerson EA, Gasse F, van Kreveld S, Holmgren K, Lee-Thorp J, Rosqvist G, Rack F, Staubwasser M, Schneider RR \& Steig EJ. (2004) Holocene climate variability. Quaternary Research 62: 243-255.

Neumann F, Schölzel C, Litt T, Hense A \& Stein M. (2007) Holocene vegetation and climate history of the northern Golan heights (Near East). Vegetation History and Archaeobotany 16: 329-346.

Nishri A \& Stiller M. (2014) Dissolved Inorganic Carbon (DIC). In: Zohary T, Sukenik A, Berman T \& Nishri A (eds) Lake Kinneret - Ecology and Management. Dordrecht: Springer, 397-415.

Nishri A, Stiller M, Rimmer A, Geifman Y \& Krom M. (1999) Lake Kinneret (The Sea of Galilee): the effects of diversion of external salinity sources and the probable chemical composition of the internal salinity sources. Chemical Geology 158: 37-52. 
Ohlendorf C \& Sturm M. (2001) Precipitation and Dissolution of Calcite in a Swiss High Alpine Lake. Arctic, Antarctic, and Alpine Research 33: 410-417.

Owen RB \& Crossley R. (1992) Spatial and temporal distribution of diatoms in sediments of Lake Malawi, Central Africa, and ecological implications. Journal of Paleolimnology 7: 55-71.

Petschick R, Kuhn G \& Gingele F. (1996) Clay mineral distribution in surface sediments of the South Atlantic: sources, transport, and relation to oceanography. Marine Geology 130: 203-229.

Pollingher U. (1986) Non-siliceous algae in a five meter core from Lake Kinneret (Israel). Hydrobiologia 143: 213-216.

Pollingher U, Ehrlich A \& Serruya S. (1984) The planktonic diatoms of Lake Kinneret (Israel) during the last 5000 years -their contribution to the algal biomass. Proceedings of the 8th International Diatom Symposium. Koeltz, 459-470.

Pross J, Kotthoff U, Müller U, Peyron O, Dormoy I, Schmiedl G, Kalaitzidis S \& Smith A. (2009) Massive perturbation in terrestrial ecosystems of the Eastern Mediterranean region associated with the 8.2 kyr BP climatic event. Geology 37: 887-890.

Rambeau C \& Black S. (2011) Palaeoenvironments of the southern Levant 5,000 BP to present: linking the geological and archaeological records. In: Mithen S \& Black E (eds) Water, Life and Civilisation: Climate, Environment and Society in the Jordan Valley. Cambridge: Cambridge University Press, 94-104.

Rambeau CM. (2010) Palaeoenvironmental reconstruction in the Southern Levant: synthesis, challenges, recent developments and perspectives. Philosophical Transactions of the Royal Society of London A: Mathematical, Physical and Engineering Sciences 368: 5225-5248.

Reches Ze \& Hoexter DF. (1981) Holocene seismic and tectonic activity in the Dead Sea area. Tectonophysics 80: 235-254.

Richter J, Hauck T, Vogelsang R, Widlok T, Le Tensorer J-M \& Schmid P. (2012) "Contextual areas" of early Homo sapiens and their significance for human dispersal from Africa into Eurasia between $200 \mathrm{ka}$ and $70 \mathrm{ka}$. Quaternary International 274: 5-24.

Rimmer A \& Givati A. (2014a) Hydrology. In: Zohary T, Sukenik A, Berman T \& Nishri A (eds) Lake Kinneret - Ecology and Management. Dordrecht: Springer, 97-112.

Rimmer A \& Givati A. (2014b) Salinity. In: Zohary T, Sukenik A, Berman T \& Nishri A (eds) Lake Kinneret - Ecology and Management. Dordrecht: Springer, 113-132.

Roberts N, Reed JM, Leng MJ, Kuzucuoğlu C, Fontugne M, Bertaux J, Woldring H, Bottema S, Black S, Hunt E \& Karabiyikoğlu M. (2001) The tempo of Holocene climatic change in the eastern Mediterranean region: new high-resolution crater-lake sediment data from central Turkey. The Holocene 11: 721-736.

Robinson SA, Black S, Sellwood BW \& Valdes PJ. (2006) A review of palaeoclimates and palaeoenvironments in the Levant and Eastern Mediterranean from 25,000 to 5000 years BP: setting the environmental background for the evolution of human civilisation. Quaternary Science Reviews 25: 1517-1541.

Roeser P, Franz SO \& Litt T. (2016) Aragonite and calcite preservation in sediments from Lake Iznik related to bottom lake oxygenation and water column depth. Sedimentology 63: 2253-2277.

Rollefson GO \& Köhler-Rollefson I. (1992) Early Neolithic Exploitation Patterns in the Levant: Cultural Impact on the Environment. Population and Environment 13: 243-254.

Rosen AM \& Rosen SA. (2017) Environmental Change and Society in Holocene Prehistory. In: Enzel Y \& Bar-Yosef $O$ (eds) Quaternary of the Levant - Environments, Climate Change, and Humans. Cambridge: Cambridge University Press 761-766.

Round F. (1978) Phythobenthos. In: Serruya C (ed) Lake Kinneret. Junk, 323-328.

Safrai V. (1994) The Economy of Roman Palestine, London: Routledge.

Schiebel V. (2013) Vegetation and climate history of the southern levant during the last 30,000 years based on palynological investigation. Bonn: Rheinische Friedrich-Wilhelms-Universität Bonn.

Schiebel V \& Litt T. (2017) Holocene vegetation history of the southern Levant based on a pollen record of Lake Kinneret (Sea of Galilee), Israel. Vegetation History and Archaeobotany. Online first publication Dec. 142017 DOI: 10.1007/s00334-017-0658-3 
Schlegel I \& Scheffler W. (1999) Seasonal development and morphological variability of Cyclotella ocellata (Bacillariophyceae) in the eutrophic Lake Dagow (Germany). Internationale Revue der gesamten Hydrobiologie 84: 469-478.

Schmidt R, Kamenik C, Lange-Bertalot H \& Rolf K. (2004) Fragilaria and Staurosira (Bacillariophyceae) from sediment surfaces of 40 lakes in the Austrian Alps in relation to environmental variables, and their potential for palaeoclimatology. Journal of limnology 63: 171-189.

Serruya C. (1978) Lake Kinneret. Monographiae Biologicae. The Hague: Dr. W. Junk bv Publishers.

Sneh A, Bartov Y, Weissbrod T \& Rosensaft M. (1998) Geological Map of Israel, 1: 200,000. Geological Survey of Israel, 4 sheets.

Stein M. (2014) Late Quaternary Limnological History. In: Zohary T, Sukenik A, Berman T \& Nishri A (eds) Lake Kinneret - Ecology and Management. Dordrecht: Springer, 39-58.

Stein M, Torfstein A, Gavrieli I \& Yechieli Y. (2010) Abrupt aridities and salt deposition in the postglacial Dead Sea and their North Atlantic connection. Quaternary Science Reviews 29: 567575.

Stiller M, Ehrlich A, Pollingher U, Baruch U \& Kaufman A. (1984) The late Holocene sediments of Lake Kinneret (Israel)-multidisciplinary study of a five meter core. Geological Survey Israel Current Research 1983-84: 83-88.

Stiller M, Rosenbaum J \& Nishri A. (2009) The origin of brines underlying Lake Kinneret. Chemical Geology 262: 293-309.

Stone JR \& Fritz SC. (2004) Three-dimensional modeling of lacustrine diatom habitat areas: Improving paleolimnological interpretation of planktic : benthic ratios. Limnology and Oceanography 49: 1540-1548.

Sukenik A, Zohary T \& Markel D. (2014) The Monitoring Program. In: Zohary T, Sukenik A, Berman T \& Nishri A (eds) Lake Kinneret - Ecology and Management. Dordrecht: Springer, 561-576.

Torfstein A \& Enzel Y. (2017) Dead Sea Lake Lavel Changes and Levant Palaeoclimate. In: Enzel Y \& Bar-Yosef $O$ (eds) Quaternary of the Levant - Environments, Climate Change, and Humans. Cambridge: Cambridge University Press, 115-125.

Torfstein A, Goldstein SL, Stein M \& Enzel Y. (2013) Impacts of abrupt climate changes in the Levant from Last Glacial Dead Sea levels. Quaternary Science Reviews 69: 1-7.

van Dam H, Mertens A \& Sinkeldam J. (1994) A coded checklist and ecological indicator values of freshwater diatoms from the Netherlands. Netherlands Journal of Aquatic Ecology 28: 117133.

Verheyden S, Nader FH, Cheng HJ, Edwards LR \& Swennen R. (2008) Paleoclimate reconstruction in the Levant region from the geochemistry of a Holocene stalagmite from the Jeita cave, Lebanon. Quaternary Research 70: 368-381.

Vossel H, Reed J, Houk V, Cvetkoska A \& Van de Vijver B. (2015) Cyclotella paleo-ocellata, a new centric diatom (Bacillariophyta) from Lake Kinneret (Israel). Fottea 15: 63-75.

Walker MJ, Berkelhammer M, Björck S, Cwynar LC, Fisher DA, Long AJ, Lowe JJ, Newnham RM, Rasmussen SO \& Weiss H. (2012) Formal subdivision of the Holocene Series/Epoch: a Discussion Paper by a Working Group of INTIMATE (Integration of ice-core, marine and terrestrial records) and the Subcommission on Quaternary Stratigraphy (International Commission on Stratigraphy). Journal of Quaternary Science 27: 649-659.

Wang L, Mackay AW, Leng MJ, Rioual P, Panizzo VN, Lu H, Gu Z, Chu G, Han J \& Kendrick CP. (2013) Influence of the ratio of planktonic to benthic diatoms on lacustrine organic matter $\mathrm{d} 13 \mathrm{C}$ from Erlongwan maar lake, northeast China. Organic Geochemistry 54: 62-68.

Williams AM. (2016) Paleolimnological implications of Late Holocene sediments in the western Sea of Galilee, Israel. Minnesota: University of Minnesota, 63.

Wilson GP, Reed JM, Lawson IT, Frogley MR, Preece RC \& Tzedakis PC. (2008) Diatom response to the Last Glacial-Interglacial Transition in the loannina basin, northwest Greece: implications for Mediterranean palaeoclimate reconstruction. Quaternary Science Reviews 27: 428-440. 
Wolin JA \& Stone JR. (2010) Diatoms as indicators of water-level change in freshwater lakes. In: Stroemer EF \& Smol JP (eds) The diatoms: Applications for the environmental and earth sciences. 2nd ed. Cambridge: Cambridge University Press, 174-185.

Woodbridge J \& Roberts N. (2011) Late Holocene climate of the Eastern Mediterranean inferred from diatom analysis of annually-laminated lake sediments. Quaternary Science Reviews 30: 33813392.

Zhang X, Reed J, Wagner B, Francke A \& Levkov Z. (2014) Lateglacial and Holocene climate and environmental change in the northeastern Mediterranean region: diatom evidence from Lake Dojran (Republic of Macedonia/Greece). Quaternary Science Reviews 103: 51-66.

Ziv B, Shilo E, Lechinsky Y \& Rimmer A. (2014) Meterology. In: Zohary T, Sukenik A, Berman T \& Nishri A (eds) Lake Kinneret - Ecology and Management. Dordrecht: Springer, 81-96.

Zohary T, Yacobi YZ, Alster A, Fishbein T, Lippman S \& Tibor G. (2014) Phytoplankton. In: Zohary T, Sukenik A, Berman T \& Nishri A (eds) Lake Kinneret - Ecology and Management. Dordrecht: Springer, 161-190.

Zuazo VcHD \& Pleguezuelo CRoR. (2008) Soil-erosion and runoff prevention by plant covers: A review. Agronomy for Sustainable Development 28: 65-86. 